\title{
IAMJ
}

INTERNATIONAL

AYURVEDIC

MEDICAL JOURNAL

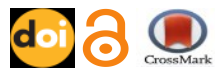

Review Article

ISSN: 23205091

Impact Factor: 5.344

\section{REVIEW ARTICLE ON JALAUKA AND JALAUKAAVCHARNA}

\section{Tandup Angial}

Assistant Professor, LBS Mahila Ayurvedic Medical College and Hospital, Sadhaura Road Bilaspur, Yamunanagar, Haryana 135102, India

Email: tandup77@gmail.com

https://doi.org/10.46607/iamj0807252020

(Published online: July 2020)

Open Access

(C) International Ayurvedic Medical Journal, India 2020

Article Received: 01/07/2020 - Peer Reviewed: 09/07/2020 - Accepted for Publication: 10/07/2020

Check for updates

\section{ABSTRACT}

The term Jalauka (leech) may be etymologically interpreted to mean creature whose life (Ayu) or whose longevity is depends upon water, whereas the derivative meaning of the term Jalauka is based upon the fact of their dwelling ("oka" - dwelling place) in water (Jalam). A creature whose life is water called Jalauka. Jalauka is having various names which are - Jalayuka, Jalaua, Jaluka etc. There are two types of treatment, advised in Ayurveda 1. Shamana (internal medicine) 2. Shodhana (internal purification). Leech therapy (Jalaukavacharana) takes a pride of place in the list of Panchakarma like Shodhana Chikitsa. Jalauka is the only shodhana treatment that can be done on rich, weak, fearful, sophisticated, old\& in case of ladies and children. Due to its sophisticated nature. The knowledge of Jalaukavacharana is as old as the Ayurveda. It is described in Rigved, kaushik sutra, VinayPitak, CharakSamhita and Sushruta Samhita. Sushruta give a detailed description of the Leech and Leech therapy. Modern medical science also describes it in detail. There are two types of Leeches six poisonous (savisha)and six nonpoisonous (nirvisha). Nirvishajalauka are strong and large Ready suckers, Greedy (Mahashana), Saivalashyava (Varna), Vrutta (round), Blue colored. Acharaya Sushruta gives a detailed description of the collection method, collection time, and preservation methods. Leech therapy or Jalaukaavcharana is mainly indicated for Pittaja and Raktaajavikara as vidradhi (Abscess), gulma (Abdominal swelling) arsha (Piles), kushtha (Skin disease) etc. Sushruta describe the method of application of leech in details dividing it into three parts namely Purvakarama, 
Pradhankarama and Pachchatkarama. Modern scientists and physicians also describe Leech and leech saliva having properties of antibiotics, anesthetic, antiseptic, anticoagulant.

Keywords: Raktaja Roga, Panchakarama, Ayurveda, Pradhan karma, Jalauka.

\section{INTRODUCTION}

A creature having its habitat and life as water is $J a$ lauka. A creature whose life (Ayu) or whose longevity is depends upon water, whereas the derivative meaning of the term Jalauka is based upon the fact of their dwelling ("oka" - dwelling place) in water(Jalam).Jalauka is having various names which are - Jalayuka, Jalaua, Jaluka, Jalaluka, Jaalalauka, Jalita, Jaloka, Jalauga, Jalatani.

Raktamokshana can be done by Jalauka in those who are rich, weak, fearful, sophisticated, old\& in the case of ladies and children. This is mildest in all the methods used for bloodletting, for which it is called the best Paramsukumarupaya. ${ }^{2}$

In Ayurveda medicines are indicated for both purposes prevention \& cure there are two types of treatment, advised in Ayurveda -

1. Shamana (internal medicine)

2. Shodhana (internal purification)

Leech therapy (Jalaukavacharana) takes a pride of place in the list of Panchakarma like ShodhanaChikitsa from the sunrise of medical history.

Acharya Sushruta has described Jalauka under the heading of Anushastra (Para sharp instrument).

According to Ayurvedic texture, only one sort of Leech is found as medicinal use, which exists in water. Jalaukavacharana is claimed to be the supreme therapy because of its high effectiveness in curing blood-related disorders. It is much safe and less com- plicated natural process, therefore, indicated even for the king, rich, old, fearful, weak, women and the people of tender nature.

\section{History-}

1. The knowledge of Jalaukavacharana is as old as the Ayurveda.

2. Reference regarding the eradication of the disease form "Usniha" (arteries) is mentioned in Rigveda. This process mostly resembles Raktamokshana.

3. The method of application of leech for bloodletting is mentioned in Kaushika Sutra which is a sutragrantha of Atharvaveda.

4. Acharya Charaka has enumerated Raktajaroga and their treatment by Shonitavasechana. ${ }^{5,6}$ and various means of Raktamokshanais also mentioned 7

5. Acharya Sushruta has dealt in detail with Raktamokshana and its type. He described a special chapter for Jalaukavacharana. The types of $J a-$ lauka, their habitat, etc. have been described the first time in detail in this chapter.

\section{Classification-}

Acharya Sushruta has classified Jalaukas into two main categories.

1. Savisha (Venomous)

2. Nirvisha (Non-venomous)

Each category again includes six varieties of Jalauka ${ }^{8}$

\begin{tabular}{|l|l|}
\hline SavishaJalauka (Poisonous) & NirvishaJalauka (Nonpoisonous) \\
\hline Krishna & Kapila \\
\hline Karbura & Pingala \\
\hline Algarda & Sankumukh \\
\hline Indrayudha & Mushika \\
\hline Samudrika & Pundarikamukhi \\
\hline Gochandana & Savarika \\
\hline
\end{tabular}


Savisha Jalauka: The Savisha Jalauka originates in the decomposed urine and fecal matter of toads and poisonous fishes in ponds of stagnant turbid water. Whereas Nirvisha Jalauka originally grows in decomposed vegetable matter, as the purified stems of the several aquatic plants known as the Padma, Utpala, Nalina, Kumuda, Pundarika, and common zoophytes, which live in clear water.

Geographical Distribution: According to Sushruta, the leeches are found in Yavana (Turkesthana) Pandya (south region country - Deccan), Sahya (the tract of land traversed by the Ghant mountains), Pautana (modern Mathura).

In Sushruta Samhita, it is described in detail. The collection of leeches is very simple. Acharya Sushruta has told that the leeches can be caught with a piece of wet leather, in tanks, streams, and where there are lotuses. There is another method to collect the leeches i.e. the fresh meat of dead animals, fish or milk must be applied on the thigh of an animal or the human being himself, may apply on his thigh and keep the thigh in the water for some time. Jalauka will attract and will catch the place. Then remove them from the skin of the person with the application of Saindhava (rock salt) and collect .4,11

Acharya Dalhana has mentioned that the best time for collecting leeches is SharadRitu (Autumn). On every third day, the water should be changed, and feeding should be dropped inside the pot. After seven days the pot should be changed. Acharya Vagbhata mentioned that the pot should be changed every five days. ${ }^{10}$

\section{Indicationsand Contraindication Indication}

Leeches are sheet in nature so commonly used in pittaj and raktaj disorders. Leeches first suck the impure blood then the pure so when the patient feels pricking pain and itching over the bite place leech should be removed. ${ }^{9}$ Vidradhi (Abscess), Gulma, Acute venous congestation $^{19}$ (Abdominal swelling), Arsha (Piles), Kushtha (Skin disease), Vatarakta (Gout), Krostrukashirsha (Infective arthritis), Osteoarthritsi Arthritis 20,21 Kantharoga (Goiter), Netraroga (Eyediseases), Granthi (Nodular swelling), Arbuda (Cancer), Shlipada (Filaria), Vidarika (Crack), Vi- shadamshtra (Insectbite), Visharpa (Erysipelas), Siroroga (Diseases of scalp), hemorrhoid ${ }^{24 .,}$ Lipodermatosclerosis $^{22}$, Vicharchika ${ }^{23}$.

Contraindications

- Sarvangashotha (Generalized edema)

- Udarroga (abdominal diseases)

- Shosa (Tuberculosis)

- Ksheena (Emaciation)

- Garbhini (Pregnancy)

- Pandu (Anemia).

Method of Application

\section{Purva Karma}

- Proper snehana (oleation) and swedana (sudation) of the patient

- Purification of Leech by pouring the Leech in water mixed with turmeric powder.

- Part preparation - Cleaning of part of the body to which leech is going to be applied.

\section{Pradhana Karma:}

Before application prick the skin with a sharp and sterile needle so that drop of blood comes out then applied the Leech through its front end and covers the leech by wet cotton. If the leech is not ready to suck the blood from the body part then the application of Madhu, Ghrit, or butter should be done.

\section{Observation of leech:}

1. Gradual distension in the central portion of the body.

2. Itching and burning sensation at the site of the bite.

3. Pulsations on the body of leech may be visible.

4. Removal of Leech: After 30-70 minutes the leech is removed by itself, or by application of turmeric powder on the mouth of the leech.

\section{Paschata Karma:}

Care of wound - After detachment of leech there is a triangular wound created by the mouth of the leech. The blood comes out from the wound. The bleeding from the wound is checked by the application of tight bandaging with the use of Yastimadhu or turmeric powder.

Induction of emesis the leech that is applied to the lesion undergoes the process of Vamana so that the same leech can be applied next time to the same pa- 
tient. For the Vamana of the leech, turmeric powder is applied over the mouth of the leech. The leech vomits out all the blood sucked by it to get purified. Sometimes pressing of Leech from caudal to the front end is required for proper emesis.

\section{Complications of Leech therapy ${ }^{13,14,15}$}

Leech therapy rarely ever leads to serious complications. The local pain of treatment and short-term itching are regular side effects. Before treatment, the patient should be advised accordingly and asked to sign a consent form describing the relevant side effects. Some of the possible reported complications are:

Local pain - Perceptions of the local pain of leeching vary. Most patients describe a local dragging pain that occurs immediately after the leech bites and persists for around one to five minutes. As more and more saliva is introduced into the tissues, the anesthetic effect of leech saliva begins to take effect.

Local itching - Transient itching at the site of the leech bite in the first few days after treatment is very common and should not be mistaken for an allergic reaction.

Septicemia and gastroenteritis - The infection caused by bacteria Aeromonashydrophilia present in the gut of Leech, which can cause pneumonia, septicemia or gastroenteritis. ${ }^{16}$

Allergic reactions - such as itching followed by burning and blister formation

Ulcerative necrosis due to toxins present in Leech saliva

Blood loss- Leech therapy is always associated with a certain degree of blood loss, which is clinically irrelevant in most cases. In the clinical trial by Michalsen, the mean hemoglobin loss was $0.7 \mathrm{mg} / \mathrm{dl}$, and clinically relevant blood loss did not occur in any of the patients studied. ${ }^{17}$

Hypotension and vasovagal attack- Patients with a history of developing vasovagal attacks or syncope (fainting) before other invasive treatment methods may also develop such a reaction at the start of or during leech therapy. ${ }^{18}$

\section{DISCUSSIONS}

Description of Jalaukaavcharan or Leech Therapy is available since Vedic Period and till date its importance is remain same beside huge development in modern science and modern technology. It is used mainly in Rakta and Pitta dosage Vayadi (disease). Due to its increasing importance in Medical field, many research articles are published on lifestyle, types, food habits and habitats of Leech. Also, researches are done on contents of saliva of leech, and indication, contraindications, and complication of leech therapy.

Presently practically Leech Therapy is used in several diseases as in case of Acne, Psoriasis, Osteoarthritis, Piles, Varicose vein, and Hair fall. But before application of leech investigation like $\mathrm{CBC}, \mathrm{HBsAg}$, AntiHCV, HIV and VDRL must be done for the safety of doctor himself and his assistant or co-workers.

In the present situation due to lack of knowledge it is very difficult to distinguish between Savish (Poisonous) and Nirvesh (Non-poisnous) by physical feature of leech except we can collect the Leech from pure water ponds or other pure water sources. Good news is that no such cases of poisonous leeches are documented all over world till date except small issues due to putting over-leeching.

\section{CONCLUSION-}

In Ayurveda, Shodhana Chikitsa has given more importance than Shamana Chikitsa because it removes the disease from its root, but it is contraindicated in garbhani, virdha, balak and sukumar except for $\mathrm{Ja}$ laukaavcharan. It is mainly indicated in the case of raktaja and Pittaja originated disease. No doubt this the procedure is time-consuming, but it is with the least invasive procedure than other surgical procedures with excellent results. 


\section{REFERENCES}

1. Sushruut Samhita: SutraSthana 13/9 Hindi commentary by Kaviraja Ambika DuttShastri, 11th Edition 1997, Chaukhambha Sanskrit sansthan, Varanasi.

2. SushruutaSamhita: Sutra Sthana 13/3 Hindi commentary by Kaviraja Ambika Dutt Shastri, 11th Edition 1997, Chaukhambha Sanskrit sansthan, Varanasi.

3. SushruutaSamhita: Sutra Sthana 13/8 Hindi commentary by Kaviraja Ambika DuttShastri, 11th Edition 1997, Chaukhambha Sanskrit sansthan, Varanasi.

4. SushruutaSamhita: Sutra Sthana 13/15-16, 35/4 Hindi commentary by KavirajaAmbikaDuttShastri, 11th Edition 1997, Chaukhambha Sanskrit sansthan, Varanasi.

5. Charaka Samhita (Hindi) Sutra sthana 24 chapter by Dr. Gorakha Natha Chaturvedi, vol -2, Edited by - Rajeswaradattasastri, chaukhambhaBharti Academy, 2004.

6. CharakaSamhita (Hindi) Chikitsa 7/52 by Dr. Gorakha Natha Chaturvedi, vol -2, Edited by - Rajeswaradattasastri, chaukhambha Bharti Academy, 2004.

7. CharakaSamhita (Hindi) Charakchikitsa 28 chapter by Dr. Gorakha Natha Chaturvedi, vol -2, Edited by - Rajeswaradattasastri, chaukhambhaBharti Academy, 2004.

8. Astanga Hridaya (Hindi) Sutra Sthana $26 / 36$ by KavirajaAtrideva Gupta, Edited by Vaidaya Yadunandana Upadhyaya, Publisher- Chaukhambha Sanskrit Sansthan 3rd Edition 2005.

9. Astanga Hridaya (Hindi) by Kaviraja Atrideva Gupta, Sutra Sthana 26/35 Edited by Vaidaya Yadunandana Upadhyaya, Publisher- Chaukhambha Sanskrit Sasthan $3^{\text {rd }}$ Edition 2005.

10. Asthanga Samgrah Sutra Sthana 35/4 Hindi Commentary by Ravi Dutta Shastri Chaukhambha Sanskrit Sasthan.

11. Asthanga Samgrah Sutra Sthana 26/36 Hindi Commentary by Ravi DuttaShastri Chaukhambha Sanskrit Sasthan.

12. Fields WS -The history of leeching and irudinHaemostasis199121Suppl 13-10 pmid:1894194 Fields WS. The history of leeching and hirudin. Haemostasis. 1991; 21 Suppl 1:3-10. [PMID: 1894194] Medline.

13. Giacometti L -Leeching in the twentieth centuryAm J Cardiol1987601128-31 pmid:3314461 Giacometti L. Leeching in the twentieth century. Am J Cardiol. 1987; 60:1128-31. [PMID: 3314461] Medline.

14. Markwardt $\mathrm{F}$-The development of hirudin as an antithrombotic drug Thromb Res1994741-23 pmid:8029805

15. Markwardt F. The development of hirudin as an antithrombotic drug. Thromb Res. 1994; 74:1-23. [PMID: 8029805] Cross Ref Medline Web of Science.

16. Markwardt $\mathrm{F}$-Hirudin as alternative anticoagulant-a historical review SeminThromb Hemost200228405-14 pmid:12420235 Markwardt F. Hirudin as alternative anticoagulant - a historical review. SeminThrombHemost. 2002; 28: 405-14. [PMID: 12420235]

17. Cross Ref Medline Web of Science Dabb RW, Malone JM, Leverett LC -The use of medicinal leeches in the salvage of flaps with venous congestionAnnPlast Surg199229250-6 pmid:1524375Dabb RW, Malone JM, Leverett LC. The use of medicinal leeches in the salvage of flaps with venous congestion. Ann Plast Surg. 1992; 29:250-6. [PMID: 1524375] CrossRefMedline.

18. Weinfeld A B, Yuksel E, Boutros S, Gura DH, Akyurek M, Friedman J D -Clinical and scientific considerations in leech therapy for the management of acute venous congestion: an updated reviewAnnPlast Surg200045207-12 pmid:10949353.

19. Weinfeld AB, Yuksel E, Boutros S, Gura DH, Akyurek $\mathrm{M}$, Friedman JD. Clinical and scientific considerations in leech therapy for the management of acute venous congestion: an updated review. Ann Plast Surg. 2000; 45:207-12. [PMID: 10949353] Medline.

20. Michalsen A, Deuse U, Esch T, Dobos G, Moebus SEffect of leeches therapy (Hirudomedicinalis) in painful osteoarthritis of the knee: a pilot study [Letter]Ann Rheum Dis200160986 pmid:11589179

21. Michalsen A, Deuse U, Esch T, Dobos G, Moebus S. Effect of leeches therapy (Hirudomedicinalis) in painful osteoarthritis of the knee: a pilot study [Letter]. Ann Rheum Dis. 2001; 60:986. [PMID: 11589179.

22. Sharad Jagtap, Bhagyashri Sakharkar. Role OF Jalauka Avacharan (Leech Therapy) in the managment of Lipodermatosclerosis: A case study. Ayushdhara ISSN: 2393-9583 (P)/ 2393-9591 (O).

23. Abhay Prakash, Arun Raj, Parikshit Debnath, Lalta Prasad, Sanjeev Prakash Exploratory Study to assess the efficiency of Jalaukaavcharan. (Hirudotherapy) in the managment of vicharchika (Eczema) International Journal of Ayurveda and Pharma Research Int. J. Ayur. Pharma Research, 2013; 1(3): 60- 65 ISSN 2322 0910.

24. Danish Javed Effect of Leech application in Prolapsed thrombosed hemorrhoid: case study International Journal of Ayurvedic Medicine. ISSN: 0976-5921. Vol 11 No 1 (2020): January - March 2020.

\section{Source of Support: Nil \\ Conflict of Interest: None Declared}

How to cite this URL: Tandup Angial: Review Article On Jalauka And Jalaukaavcharna. International Ayurvedic Medical Journal \{online\} 2020 \{cited July, 2020\} Available from:

http://www.iamj.in/posts/images/upload/3973 3977.pdf 